\title{
Membangun Aplikasi Chatbot Berbasis Web Pada CV. Unomax Indonesia
}

\author{
Teddy Wijaya ${ }^{1)}$, Muhammad Rusli²), Erwin Syah Rany ${ }^{3)}$, Harfebi Fryonanda ${ }^{4)}$ \\ Sistem Informasi, Institut Teknologi dan Bisnis Kalbis \\ Jalan Pulomas Selatan Kav. 22, Jakarta 13210 \\ ${ }^{1)}$ Email: tdiewijaya@yahoo.com \\ ${ }^{2)}$ Email: muhammad.rusli@kalbis.ac.id \\ 3)Email: erwin.srany@yahoo.com \\ 4)Email: harfebi.fryonanda@kalbis.ac.id
}

\begin{abstract}
The development of Internet technology is widely used for positive things in helping human work, one of which facilitates communication between humans. In this case, CV. Unomax Indonesia is still relying on human as an online customer service to respond to inquiries from customers. As customers grow, it is less effective for customers who want to get quick reply information without time constraints. This study aims to create a web-based information system in the form of chatbot application that can be used by CV. Unomax Indonesia to respond to customer inquiries quickly. The method used is the prototype method as a modeling tool. This application uses PHP programming language and MySQL database. The result of the built chatbot application is based on test results using black box testing, it can be concluded that this application can run well and answer each question quickly as expected.
\end{abstract}

Keywords: chatbot, customer service, information system, system, web

\begin{abstract}
Abstrak: Perkembangan teknologi internet banyak digunakan untuk hal-hal positif dalam membantu pekerjaan manusia, salah satunya memudahkan komunkiasi antar manusia. Dalam hal ini, CV. Unomax Indonesia saat ini masih mengandalkan manusia sebagai customer service online untuk menanggapi pertanyaan dari pelanggan. Seiring pelanggan yang semakin meningkat, hal tersebut dirasa kurang efektif bagi pelanggan yang ingin mendapatkan informasi balasan dengan cepat tanpa keterbatasan waktu. Penelitian ini bertujuan untuk membuat sistem informasi berbasis web berupa aplikasi chatbot yang dapat digunakan oleh CV. Unomax Indonesia untuk menanggapi pertanyaan pelanggan secara cepat. Metode yang digunakan adalah metode prototype sebagai alat pemodelannya. Aplikasi ini menggunakan bahasa pemrograman PHP dan database MySQL. Hasil dari dibangunnya aplikasi chatbot ini berdasarkan hasil pengujian menggunakan black box testing, dapat disimpulkan bahwa aplikasi ini dapat berjalan dengan baik dan menjawab setiap pertanyaan dengan cepat sesuai yang diharapkan.
\end{abstract}

Kata kunci: chatbot, customer service, sistem, sistem informasi, web

\section{PENDAHULUAN}

Peralihan gaya hidup melalui pemanfaatan teknologi informasi sedang berjalan dengan sangat cepat. Perkembangan teknologi infomasi tidak lepas dari pesatnya perkembangan teknologi komputer, karena komputer merupakan media yang dapat memberikan kemudahan bagi manusia dalam menyelesaikan suatu pekerjaan. Didukung dengan mudahnya akses internet semakin menunjang perkembangan teknologi komputer. Dalam dunia internet, segala informasi dapat diakses dengan sangat mudah tanpa terbatas ruang dan waktu.

Pengguna internet di Indonesia bertumbuh dengan sangat pesat, internet kini bukan lagi barang mewah atau sesuatu yang langka dimiliki oleh msyarakat di Indonesia. Laporan teranyar dari hasil survei yang dilakukan oleh Asosiasi Penyelenggara Jasa Internet Indonesia (APKII) pada tahun 2017 jumlah pengguna internet di Indonesia mencapai 143,26 juta orang. Dari jumlah tersebut mencakup 54,68 persen dari total populasi masyarakat Indonesia yang mencapai 262 juta orang [1].

Perkembangan teknologi internet banyak digunakan untuk hal-hal positif untuk membantu pekerjaan manusia, salah satunya untuk memudahkan komunikasi antar manusia. Dalam hal ini, CV. Unomax Indonesia ingin membangun sebuah sistem informasi untuk membantu memudahkan komunikasi antara customer service dengan pelanggan secara 
cepat. CV. Unomax Indonesia merupakan perusahaan yang bergerak dibidang e-commerce atau online retail yang menjual berbagai aksesoris gadget premium.

Pada saat ini CV. Unomax Indonesia masih mengandalkan manusia sebagai customer service online yang ditugaskan untuk menanggapi semua pertanyaan dari pelanggan. Berdasarkan wawancara dengan Bapak Hendy Sutanto selaku direktur di CV. Unomax Indonesia, saat ini CV. Unomax Indonesia memiliki 2 orang customer service yang menanggapi pertanyaan pelanggan rata-rata mencapai 20 orang setiap harinya dengan keterbatasan waktu pada jam kerja, sehingga sering terjadi lambatnya respon kepada pelanggan pada saat banyaknya pertanyaan yang masuk dan pertanyaan yang masuk diluar jam kerja. Apabila saat tingginya intensitas pelanggan, setiap harinya bisa mencapai 35 orang pelanggan yang harus dilayani oleh customer service dimana 7 orang pelanggan diantaranya bertanya diluar jam kerja sehingga baru dapat ditanggapi pada keesokan harinya. Seiring berkembangnya perusahaan, pelanggan yang semakin meningkat dan terbatasnya kemampuan manusia dalam hal ini adalah customer service dalam menanggapi pertanyaan pelanggan dengan cepat. Hal tersebut dirasa kurang efektif bagi pelanggan yang ingin mendapatkan informasi balasan dengan cepat tanpa keterbatasan waktu.

Dengan dibangunnya sebuah sistem informasi pada CV. Unomax Indonesia diharapkan dapat menjadi solusi atas permasalahan-permasalahan yang ada. Pertanyaan dapat ditanggapi dengan cepat dan tanggap tanpa mengenal keterbatasan waktu. Tujuan akhirnya adalah memberikan pelayanan yang terbaik untuk pelanggan dan meningkatkan keuntungan bagi perusahaan. Berdasarkan uraian latar belakang di atas, perlu adanya solusi untuk mengatasi masalahmasalah di atas dan memaksimalkan sumber daya yang tersedia. Oleh karena itu, penulis berusaha membangun sebuah aplikasi Chatbot yang dapat digunakan untuk menanggapi pertanyaan pelanggan secara cepat pada CV. Unomax Indonesia.

\section{METODE PENELITIAN}

Metode yang digunakan dalam penelitian ini adalah metode prototype. Ide dasar dalam model prototype adalah bahwa alih-alih membekukan persyaratan sebelum desain atau pengkodean dapat dilanjutkan, prototype sekali pakai dibangun untuk memahami persyaratan. Prototype ini dikembangkan berdasarkan persyaratan yang diketahui saat ini. Model prototype adalah model pengembangan perangkat lunak. Dengan menggunakan prototype ini, klien bisa mendapatkan "nuansa sebenarnya" dari sistem, karena interaksi dengan prototype dapat memungkinkan klien untuk lebih memahami persyaratan sistem yang diinginkan. Prototype adalah ide yang menarik untuk sistem yang rumit dan besar yang tidak ada proses manual atau sistem yang ada untuk membantu menentukan persyaratan.

Prototype biasanya bukan sistem yang lengkap dan banyak rinciannya tidak dibangun dalam prototype. Tujuannya adalah untuk menyediakan sistem dengan fungsi keseluruhan [2]. Berikut adalah model prototype seperti pada Gambar 1.

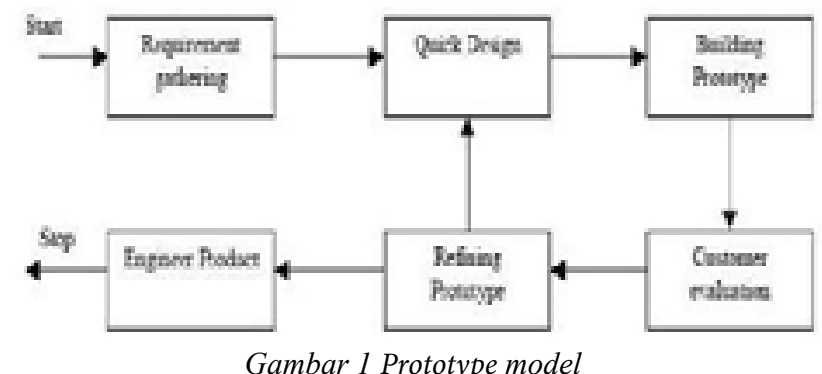

\section{A. Tahapan Pengembangan dalam Metode Prototype}

Dalam tahapan ini merupakan kerangka pemikiran yang berisi langkah-langkah metodologi yang dilakukan oleh peneliti dalam penelitian ini. Menggunakan metode prototype, berikut adalah

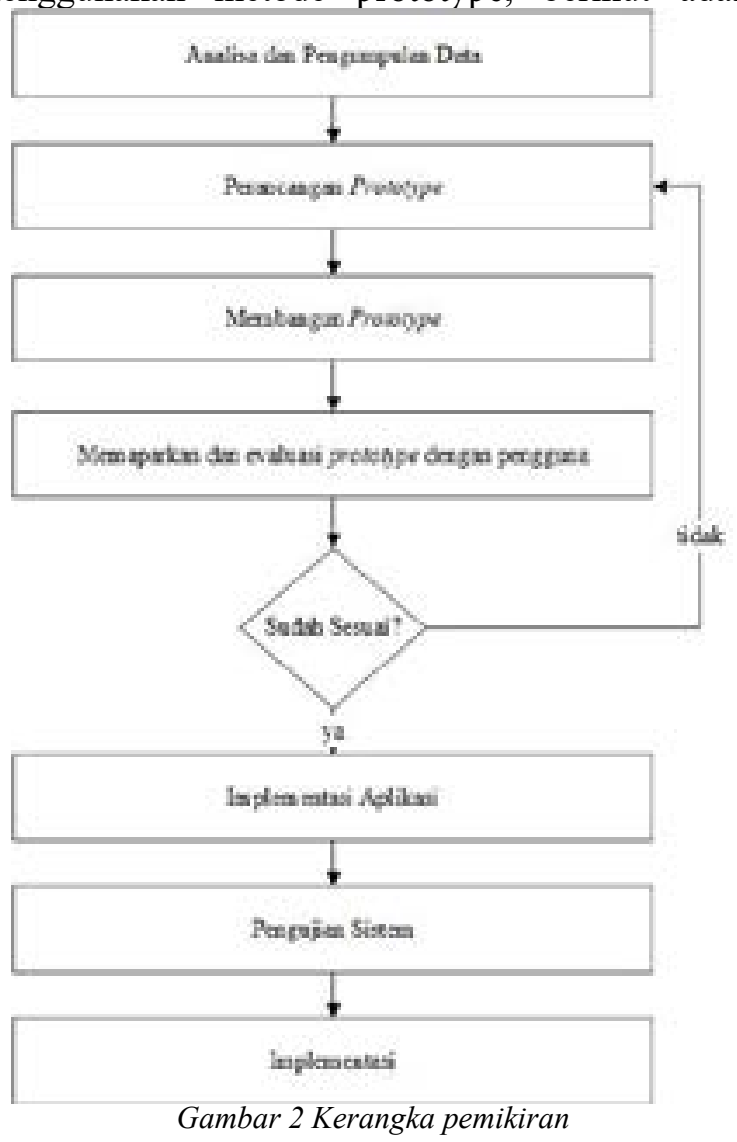


langkah-langkah dalam penelitian ini secara garis besar seperti pada Gambar 2.

Penjelasan Gambar 2:

1. Peneliti melakukan komunikasi melalui wawancara pada awal penelitian dan setiap tahap rancangan selama proses pengembangan sistem. Selain melalui wawancara, peneliti juga melakukan observasi langsung untuk mengamati proses bisnis yang berangsung. Berdasarkan komunikasi dan identifikasi yang dilakukan, peneliti mencatat setiap data dan informasi penting yang diperlukan. Kemudian peneliti melakukan analisa sistem yang berjalan saat ini, mengidentifikasi permasalahan yang ada, melakukan analisa sistem usulan serta menganalisa kebutuhan fungsional dan non fungsional yang diperlukan pada sistem yang baru.

2. Setelah itu peneliti membuat perancangan sistem, perancangan basis data, perancangan antar muka, dan perancangan pengujian. Pada perancangan sistem peneliti menggunakan Unified Modeling Language (UML). Untuk perancangan basis data peneliti menggunakan Entity Relationship Diagram (ERD) untuk level konseptual, class diagram untuk level logika, dan struktur tabel untuk level fisik. Untuk perancangan antar muka peneliti menggunakan aplikasi Balsamiq.

3. Saat pembangunan prototype dilakukan, peneliti membangun bagian prototype yang sudah sesuai menjadi sistem sesungguhnya yaitu pengkodean sistem. Pengkodean sistem ini nantinya akan menjadi sistem yang sesungguhnya yaitu berupa tampilan antar muka aplikasi berbasis web.

4. Secara keseluruhan dari perancangan dan implementasi prototype yang sudah dibuat, prototype sudah dibuat sesuai dengan keinginan pengguna. Peneliti mendemokan halaman web interaktif yang sudah dibuat kepada pengguna dan pengguna sudah merasa sesuai dengan apa yang diinginkan.

5. Apabila sudah sesuai dengan keinginan pengguna maka dilakukan implementasi aplikasi. Dalam tahap ini akan ditentukan Batasan pengetahuan aplikasi, pengelolaan batasan aplikasi dan pengkodean sistem. Pengkodean sistem ini nantinya akan menjadi sistem yang sesungguhnya yaitu berupa aplikasi. Peneliti membangun aplikasi berbasis web dengan menggunakan bahasa pemrograman Hypertext Preprocessor (PHP) dan Basis Data My Structure Query Language (MySQL).

6. Pengujian Sistem dalam skripsi ini menggunakan metode black box testing. Tahap pengujian black box testing merupakan proses melakukan evaluasi terhadap cara kerja sistem aplikasi yang sudah diimplementasikan dalam penelitian ini. Dalam pengujian black box testing, akan dibuat terlebih dahulu rencana pengujian dan skenario pengujian yang akan dilakukan terhadap sistem. Setelah dibuat rencana pengujian dan skenario pengujian maka akan dilakukan pengujian sistem apakah sudah sesuai atau belum dengan rencana pengujian dan skenario pengujian yang telah dibuat. Pada bagian akhir akan ditarik kesimpulan dari pengujian black box testing ini.

7. Jika seluruh tahapan telah berhasil dilakukan dan sudah sesuai, maka aplikasi siap untuk diimplementasikan lalu akan ditarik kesimpulan dan saran dari penelitian ini.

\section{B. Konsep Dasar Sistem}

Sistem merupakan suatu jaringan kerja yang terdiri dari beberapa prosedur dan saling berhubungan dalam melakukan kegiatan unuk mencapai tujuan tertentu. Menurut Richard F Neuschel, prosedur merupakan suatu operasi yang terjadi dan melibatkan beberapa sumber daya di dalam suatu perusahaan dalam menangani proses bisnis yang terjadi [3].

\section{Konsep Dasar Sistem Informasi}

Sistem informasi sebagai penyedia informasi yang kemudian digunakan untuk pengambilan keputusan pada perencanaan, pengendalian, pengorganisasian dalam suatu operasi subsistem di sebuah perusahaan. Sistem informasi berperan penting dalam bidang bisnis, karena dapat membantu meningkatan efisiensi dan efektifitas melalui pengambilan keputusan dalam mempertahankan persaingan antar kompetitor [3].

\section{Sistem Informasi}

Sistem informasi adalah suatu bentuk sistem komunikasi yang didalamnya berfungsi untuk pengolahan kebutuhan transaksi harian, mendukung operasi, kegiatan manajerial, dan kegiatan strategis dari suatu organisasi dimana data direpresentasikan dan diproses sebagai bentuk memori sosial yang mendukung dalam proses pengambilan keputusan dan tindakan [4].

Dalam suatu sistem informasi terdapat komponen-komponen yaitu: 1) Perangkat keras (hardware), merupakan piranti fisik seperti komputer dan printer; 2) Perangat lunak (software) atau disebut juga program, yaitu sekumpulan kode atau instruksi agar perangkat keras dapat memproses data; 3) Prosedur, yaitu kumpulan yang digunakan dalam memproses data untuk menghasilkan output yang 
sesuai dengan tujuan; 4) Resources, merupakan pihak yang memiliki tanggung jawab untuk mengembangkan sistem informasi, proses sistem dan sistem yang akan dihasikan; 5) Basis data (database), adalah sekumpulan tabel, relasi yang berkaitan dengan penyimpanan data; dan 6) Jaringan komputer dan komunikasi data, sistem penghubung yang memungkinkan digunakan oleh resources secara bersama atau dengan jumlah tertentu.

\section{E. Website}

Website adalah keseluruhan halaman-halaman web yang terdapat dalam sebuah domain yang mengandung informasi. Sebuah website biasanya dibangun atas banyak halaman web yang saling berhubungan. Hubungan antara satu halaman web dengan halaman web yang lainnya disebut dengan hyperlink, sedangkan teks yang dijadikan media penghubung disebut hypertext [5].

Domain adalah nama unik yang dimiliki oleh sebuah institusi sehingga bisa diakses melalui internet, misalnya yahoo.com, google.com, dan lain-lain. Untuk mendapat sebuah domain kita harus melakukan register pada registar-registar yang ditentukan. Istilah lain yang sering ditemui sehubungan dengan website adalah homepage. Homepage adalah halaman awal sebuah domain.

\section{F. Kecerdasan Buatan}

Kecerdasan buatan (artificial inteligence) adalah salah satu bidang ilmu komputer yang mendayagunakan komputer, sehingga dapat berperilaku cerdas seperti manusia. Ilmu komputer tersebut mengembangkan perangkat lunak dan perangkat keras untuk menirukan tindakan manusia. Aktivitas manusia yang ditirukan seperti penalaran, penglihatan, pembelajaran, pemecahan masalah, pemahaman bahasa alami dan sebagainya [6].

Teknologi kecerdasan buatan dapat dipelajari dalam berbagai bidang bidang seperti Robotika (robotics), penglihatan komputer (computer vision), pengolahan bahasa alami (natural language processing), pengenalan pola (pattern recognitiion), system syaraf buatan (artificial neural system), pengenalan suara (speech recognition) dan system pakar (expert system).

Kecerdasan buatan ditujukan dalam perancangan otomatisasi tingkah laku cerdas dalam sistem kecerdasan komputer. Bagian utama dari kecerdasan buatan adalah basis pengetahuan (knowledge base), yaitu suatu pengertian atau pemahaman tentang wilayah subjek yang diperoleh melalui pembelajaran dan pengalaman.

\section{G. Chatbot}

Chatbot berasal dari dua kata yaitu chat dan bot. Dalam dunia komputer chat dapat diartikan sebagai kegiatan komunikasi yang menggunakan sarana tulisan. Sedangkan bot merupakan program yang memiliki sejumlah data yang beli diberi input akan menghasilkan output sebagai jawaban. Dari dua istilah diatas dapat diartikan bahwa chatbot adalah program komputer yang dapat melakukan percakapan melalui media tulisan. Percakapan dapat terjadi dengan manusia atau chatbot yang lain [7].

\section{H. Customer Service}

Customer Service adalah setiap kegiatan yang diperuntukkan atau ditujukan untuk memberikan kepuasan melalui pelayanan yang diberikan seseorang kepada nasabah. Pelayanan yang diberikan termasuk menerima keluhan/masalah yang sedang dihadapi. Seorang customer service harus pandai dalam mencari jalan keluar untuk menyelesaikan masalah yang dihadapi oleh nasabahnya. Hubungan yang baik dengan nasabah merupakan salah satu bukti dari keberhasilan pelayanan yang dilakukan oleh perusahaan. Dengan adanya pelayanan yang memuaskan bagi nasabah atau konsumen, maka konsumen atau nasabah tidak akan terpikir untuk mencoba pelayanan dan produk yang ditawarkan oleh perusahaan lain [8].

\section{PHP}

Personal Home Page atau PHP adalah suatu bahasa pemrograman yang dapat digunakan untuk tujuan umum seperti bahasa pemrograman lain. $P H P$ lebih populer digunakan untuk pengembangan dalam aplikasi web. PHP adalah program opensource dan bersifat bebas sehingga dapat dijalankan di sebagian besar sistem operasi [9].

\section{J. MySQL}

My Structured Query Language atau MySQL adalah salah satu jenis database server yang sangat terkenal dan banyak digunakan untuk membangun aplikasi web yang menggunakan database sebagai sumber dan pengolahan datanya. MySQL dikembangkan oleh perusahaan Swedia bernama MySQL AB yang pada saat ini bernama Tcx DataKonsult AB sekitar tahun 1994-1995, namun cikal bakal kodenya sudah ada sejak tahun 1979 . Awalnya Tcx merupakan perusahaan pengembang 
software dan konsultan database, dan saat ini MySQL sudah diambil alih oleh Oracle Corp [10].

Kepopuleran MySQL antara lain karena MySQL menggunakan SQL sebagai bahasa dasar untuk mengakses databasenya sehingga mudah untuk digunakan, kinerja query cepat, dan mencukupi untuk kebutuhan database perusahaan-perusahaan yang berskala kecil sampai menengah, MySQL juga bersifat open source (tidak berbayar) .

MySQL merupakan database yang pertama kali didukung oleh bahasa pemrograman script untuk internet (PHP dan Perl). MySQL dan PHP dianggap sebagai pasangan software pembangun aplikasi web yang ideal. MySQL lebih sering digunakan untuk membangun aplikasi berbasis web, umumnya pengembangan aplikasinya menggunakan bahasa pemrograman script PHP.

MySQL didistribusikan dengan licensi open source GPL (General Public License) mulai versi 3.23 pada bulan Juni 2000. Software MySQL bisa diunduh melalui website resminya di http://www.MySQL.org atau di http://www.mysql.com.

\section{K. Flowchart}

Flowchart atau bagan alir merupakan metode untuk menggambarkan tahap-tahap penyelesaian masalah (prosedur) beserta aliran data dengan simbolsimbol standar yang mudah dipahami [11]. Flowchart dibedakan dalam tiga kategori, yakni: 1) Flowchart Dokumen. Flowchart dokumen menggambarkan aliran data dan informasi antar-area (divisi) dalam sebuah organisasi; 2) Flowchart Sistem. Flowchart sistem lebih menekankan pada gambaran tentang aliran input, prosedur pemrosesan, dan output yang dihasilkan sistem; dan 3) Flowchart Program

Flowchart program lebih banyak digunakan untuk menggambarkan logika suatu prosedur penyelesaian masalah dalam pemrograman komputer.

\section{Penelitian Sebelumnya}

Adapun penelitian sebelumnya sebagai landasan dalam mendukung penelitian adalah sebagai berikut: 1) Penelitian oleh R. B. Santoso dengan judul Rancang Bangun Prototype Chat Bot Customer Service System Berbasis Web. Hasil dari penelitian tersebut adalah Chatbot berhasil menjawab semua konsultasi nasabah dengan cepat sesuai yang sudah direpresentasikan di dalam database [6];2) Penelitian oleh E. Nila, I. Afrianto dengan judul Rancang Bangun Aplikasi Chatbot Informasi Objek Wisata Kota Bandung Dengan Pendekatan Natural Language Processing. Hasil dari penelitian tersebut adalah pengguna sangat terbantu dengan adanya informasi yang cepat melalui aplikasi Chatbot ini [12]; 3) Penelitian oleh B. Setiaji, E. Utami, H. A. Fatta dengan judul Membangun Chatbot Berbasis AIML Dengan Arsitektur Pengetahuan Modular. Hasil dari penelitian tersebut adalah menghasilkan service yang dapat digunakan untuk percakapan dengan pengguna menggunakan perantara bahasa alami [7];4) Penelitian oleh S. Gupta, et. al. dengan judul An E-Commerce Website Based Chatbot. Hasil dari penelitian tersebut adalah Penerapan Chatbot pada website E-Commerce meningkatkan interaksi pengguna dengan situs web E-Commerce [13]; dan 5) Penelitian oleh H. Joshi, et. al. dengan judul Proposal Of Chat Based Automated System For Online Shopping. Hasil dari penelitian tersebut adalah meningkatkan interaksi pengguna dengan customer service pada E-Commerce [14].

\section{HASIL DAN PEMBAHASAN}

\section{A. Analisa Masalah}

Ditahap ini peneliti melakukan analisa masalah seperti analisa sistem berjalan, analisa permasalahan, usulan pemecahan masalah, analisa kebutuhan sistem dan analisa kebutuhan data.

\section{Analisa Sistem Berjalan}

Saat ini CV Unomax Indonesia masih mengharuskan pelanggan untuk berkomunikasi dengan customer service untuk mengajukan pertanyaan melalui chatting seperti Whatsapp, Line, ataupun melalui SMS. Sistem lama yang saat ini digunakan adalah pelanggan harus mengantri untuk menanyakan pertanyaan dengan customer service pada jam kerja kemudian customer service akan memberikan jawaban kepada pelanggan seperti pada Gambar 3.

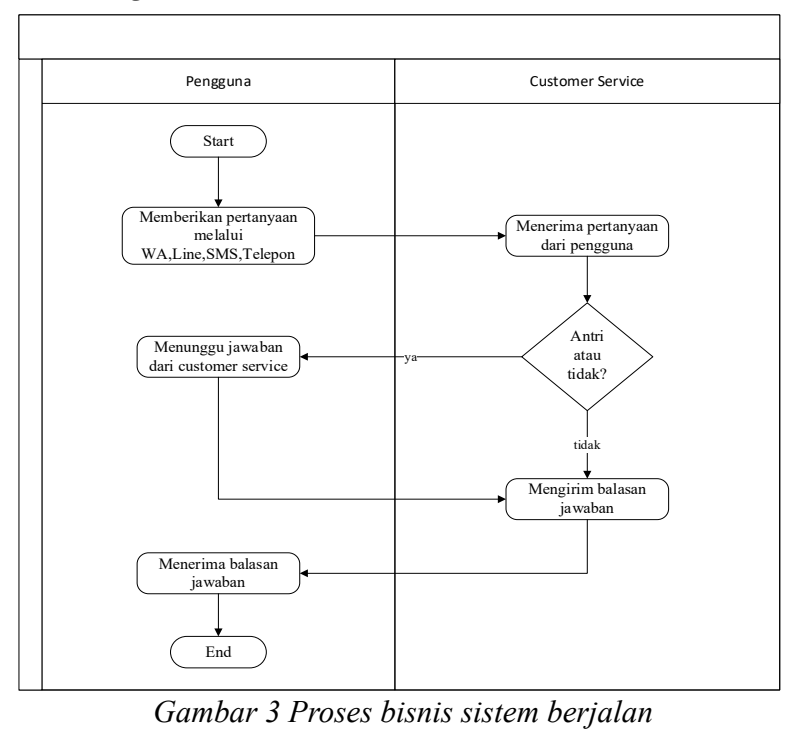




\section{Analisa Permasalahan}

Setelah dilakukan pengkajian sistem berjalan pada CV Unomax Indonesia, maka diperoleh gambaran permasalahan sistem yang berjalan dalam uraian berikut: (a) Sering terjadinya waktu tunggu yang lama pada saat pelanggan berkomunikasi dengan customer service, hal tersebut dikarenakan menumpuknya pelanggan dalam suatu waktu tertentu. Hal ini juga diakibatkan karena pelanggan bertanya kepada customer service diluar jam kerja; (b) Seiring berkembangnya perusahaan, pelanggan yang semakin meningkat dan terbatasnya kemampuan manusia dalam hal ini adalah customer service dalam menanggapi pertanyaan pelanggan dengan cepat. Hal tersebut dirasa kurang efektif bagi pelanggan yang ingin mendapatkan informasi balasan dengan cepat tanpa keterbatasan waktu; dan (c) CV. Unomax Indonesia berkomitmen untuk menyediakan pelayanan dan produk yang terbaik dengan harga yang terjangkau bagi pelanggan. Salah satu pelayanan terbaik yg harus diberikan adalah melalui customer service yang dapat menanggapi pertanyaan pelanggan dengan cepat. Oleh karena itu, hal ini menjadi permasalahan yang cukup penting bagi CV. Unomax Indonesia.

\section{Usulan Pemecahan Masalah}

Setelah melakukan pengkajian terhadap sistem berjalan dan permasalahan yang ada, maka akan dibangun sistem baru untuk menanggapi pertanyaan pelanggan dengan cepat. Pada tahap analisa ini akan dibangun sebuah aplikasi chatbot yang dapat menanggapi pertanyaan pelanggan secara otomatis. Sistem yang dibangun menggunakan Bahasa pemrograman PHP dan database MySQL. Pada aplikasi chatbot yang dibangun tersebut, diberikan halaman untuk chatting yang digunakan pelanggan untuk memasukkan pertanyaan dan aplikasi chatbot akan memberikan jawaban sesuai dengan representasi pengetahuan yang diberikan.

\section{B. Perancangan Prototype}

Ditahap ini peneliti melakukan perancangan prototype yaitu berupa perancangan sistem menggunakan UML, perancangan basis data menggunakan ERD dan perancangan antar muka.

\section{Perancangan Sistem}

Perancangan sistem dalam penelitian ini menggunakan Unified Modeling Language (UML). Didalam UML ini berisikan Use Case Diagram,
Activity Diagram, Sequence Diagram dan Class Diagram.

a. Use Case Diagram. Use case diagram merupakan pemodelan untuk kelakukan (behavior) sistem informasi yang akan dibuat. Use case mendeskripsikan sebuah interaksi antara satu atau lebih aktor dengan sistem informasi yang akan dibuat. Dapat dikatakan use case digunakan untuk mengetahui fungsi apa saja yang ada di dalam sistem informasi dan siapa saja yang berhak menggunakan fungsi-fungsi tersebut [15]. Use Case Diagram menggambarkan fungsionalitas yang diharapkan dalam sebuah sistem yang akan dibangun, juga merepresentasikan interaksi antara aktor dengan sistem seperti pada Gambar 4.

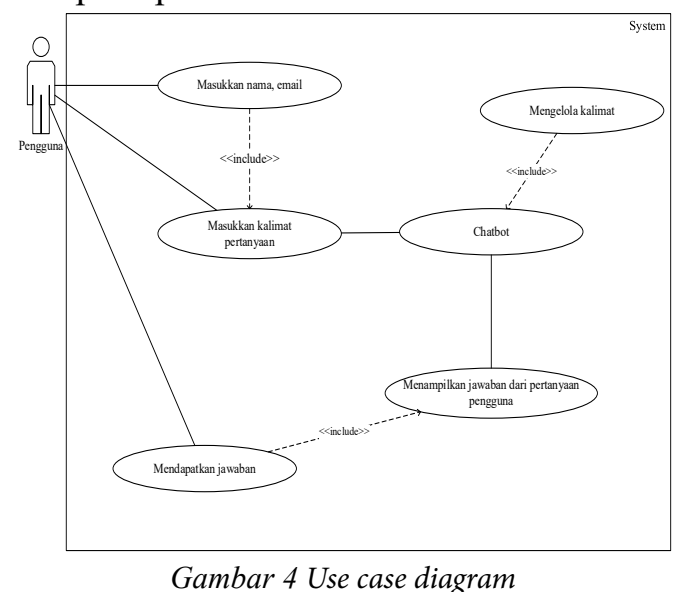

b. Activity Diagram. Activity Diagram menggambarkan workflow (aliran kerja) atau aktivitas dari sebuah sistem atau proses bisnis [15]. Activity Diagram memperlihatkan aliran proses dari suatu aktivitas ke aktivitas lainnya dalam sebuah sistem yang dibangun. Diagram ini lebih menekankan penggambaran proses dan jalur aktivitas secara umum seperti pada Gambar 5.

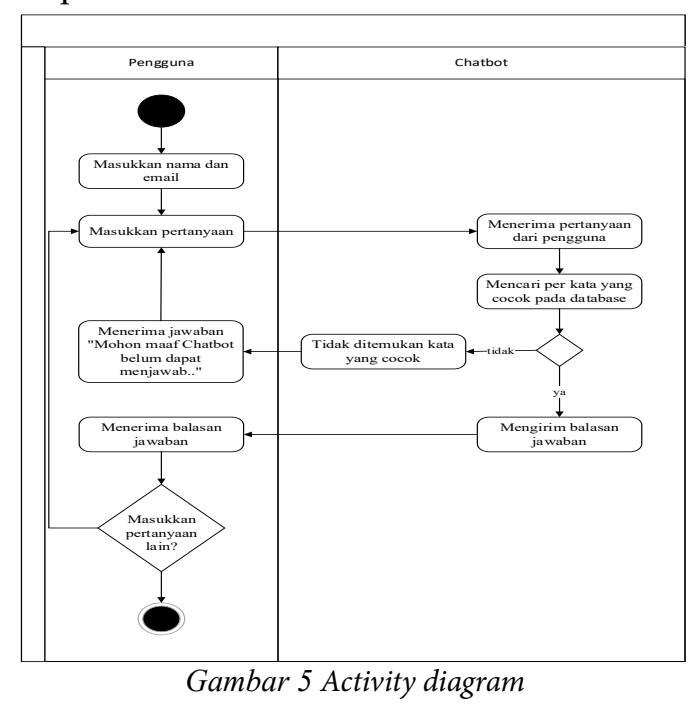

c. Sequence Diagram. Sequence diagram menggambarkan kelakuan objek pada use case 
dengan mendeskripsikan waktu hidup objek dan pesan yang dikirimkan dan diterima antar objek [15]. Sequence Diagram merupakan diagram interaksi yang menggambarkan skenario atau rangkaian langkah dari sebuah event untuk menghasilkan output. Diawali dari apa yang men-trigger aktivitas tersebut, proses dan perubahan yang terjadi secara internal dan output apa yang dihasilkan seperti pada Gambar 6 .

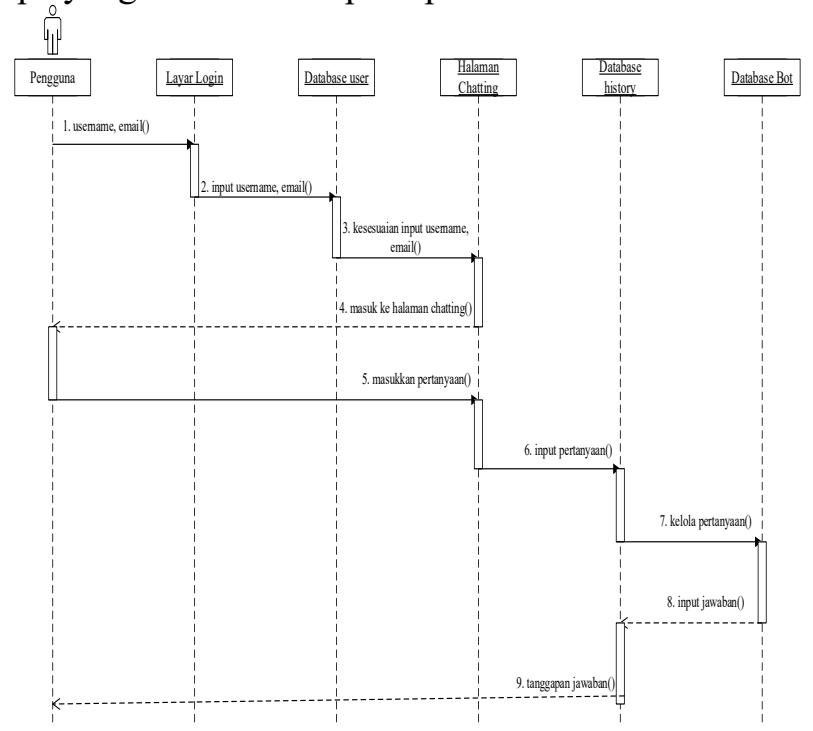

Gambar 6 Sequence diagram

d. Class Diagram. Class Diagram merupakan hubungan antar kelas dan penjelasan detail tiaptiap kelas di dalam model desain dari suatu sistem, juga memperlihatkan aturan-aturan dan tanggng jawab entitas yang menentukan perilaku sistem. Class diagram juga menunjukkan atribut-atribut dan operasi-operasi dari sebuah kelas dan constraint yang berhubungan dengan objek yang dikoneksikan. Class diagram secara khas meliputi: Kelas (Class), Relasi, Associations, Generalization dan Aggregation, Atribut (Attributes), Operasi (Operations/Method), Visibility, tingkat akses objek eksternal kepada suatu operasi atau atribut [15]. Class diagram menggambarkan struktur dan deskripsi class, package dan objek. Didalamnya juga terdapat hubungan satu sama lain seperti containment, pewarisan, asosiasi, dan lain-lain seperti pada Gambar 7.

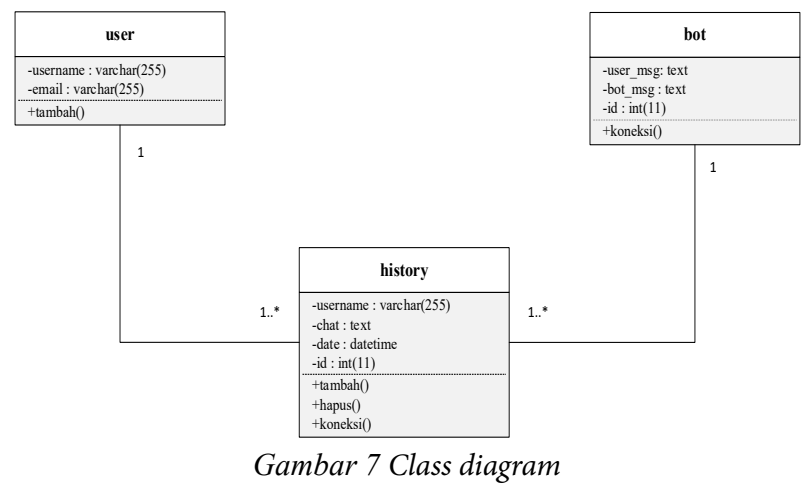

\section{Perancangan Basis Data}

Pada tahapan ini akan dilakukan perancangan basis data yang akan digunakan. Basis data ini nantinya akan digunakan dalam sistem yang akan dibangun dalam menyimpan data-data yang diperlukan. Perancangan basis data ini menggunakan entity relationship diagram dan struktur tabel.

Entity Relationship Diagram menjadi salah satu pemodelan data konseptual yang paling sering digunakan dalam proses pengembangan basis data bertipe relasional. Model E-R sering digunakan sebagai sarana komunikasi antara perancang basis data dan pengguna sistem selama tahap analisa atau perancangan dari porses pengembangan basis data dalam kerangka pengembangan sistem informasi secara utuh. Model E-R digunakan untuk mengkonstruksi model data konseptual, yang mencerminkan struktur data dan batasan dari basis data, serta berhubungan erat dengan model data yang langsung bisa digunakan untuk mengimplementasikan basis data secara logika maupun secara fisik dengan DBMS yang dipilih pada tahap implementasi. ERD adalah suatu diagram untuk menggambarkan desain konseptual dari model konseptual suatu basis data relasional. ERD juga merupakan gambaran yang merelasikan antara objek yang satu dengan objek yang lain dari objek di dunia nyata yang sering dikenal dengan hubungan entitas [16].

Sebelum menbuat ERD, peneliti menentukan terlebih dahulu bagian-bagian yang akan dirancang. Bagian tersebut antara lain penentuan entitas dan penentuan atribut pada setiap entitas yang digunakan dalam perancangan basis data dalam penelitian ini. Dari entitas dan atribut yang ditentukan, akan dibuat relasi keterhubungan dan derajat kardinalitas antar entitas yang memiliki relasi dalam bentuk diagram lengkap yang disebut entity relationship diagram. Beberapa atribut pada entitas user dapat dilihat pada Tabel 1, Beberapa atribut pada entitas bot dapat dilihat pada Tabel 2, Beberapa atribut pada entitas history dapat dilihat pada Tabel 3 .

Tabel 1 Entitas user

\begin{tabular}{ll}
\hline Nama Field & Keterangan \\
\hline usemame & Namapengguna \\
\hline email & Emalpengguna \\
\hline
\end{tabular}

Pembuatan ERD. Pada tahap ini akan dilakukan pembuatan ERD seperti pada Gambar 8. Penelitian ini menggunakan 3 buah tabel yaitu tabel pengguna, tabel pengetahuan dan tabel percakapan. Tabel Pengguna, digunakan untuk menyimpan data pengguna yaitu username dan email seperti pada Tabel 4. 
Tabel 2 Entitas bot

\begin{tabular}{ll}
\hline Nama Field & Keterangan \\
\hline user_msg & $\begin{array}{l}\text { Kata kunciberdasarkan } \\
\text { pertanyaan dari pengguna }\end{array}$ \\
\hline bot_msg & $\begin{array}{l}\text { Balasanjawabon dari } \\
\text { pertanyaanyang diajukan } \\
\text { pengguna }\end{array}$ \\
& $\begin{array}{l}\text { Idpengetahuan (atnbut } \\
\text { identitas) }\end{array}$ \\
\hline
\end{tabular}

Tabel 3 Entitas history

\begin{tabular}{ll}
\hline Nama Field & Keterangan \\
\hline usemame & $\begin{array}{l}\text { Nama pengguna yang ak an } \\
\text { munculpada tampilan } \\
\text { percakapan }\end{array}$ \\
\hline chat & $\begin{array}{l}\text { Petcakapan pertanyaan } \\
\text { pengguna danjawaban } \\
\text { chatbot }\end{array}$ \\
date & $\begin{array}{l}\text { Waktupesan pertanyaan } \\
\text { pengguna ataujawaban } \\
\text { chatbot dakinm }\end{array}$ \\
\hline ad & Id history (atnbut identitas)
\end{tabular}

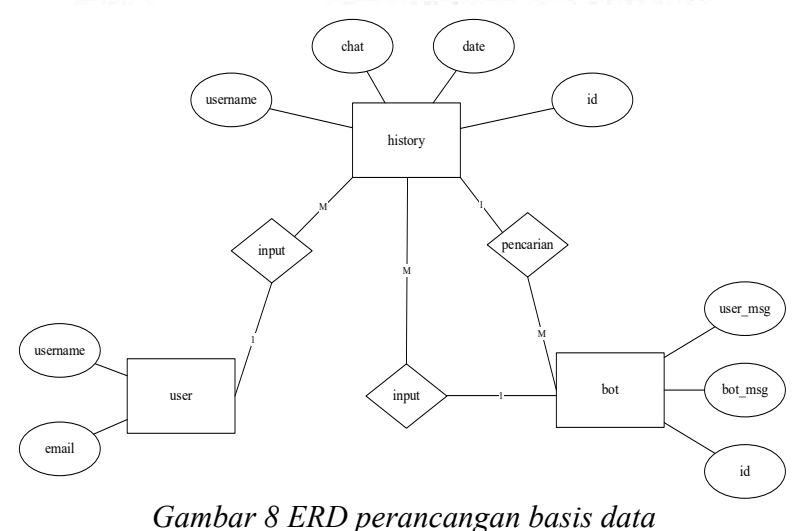

Tabel 4 Tabel pengguna

\begin{tabular}{lll}
\hline No & Nama & Tipe Data \\
\hline 1 & usemame & varchar $(255$ \\
\hline 2 & email & varchar 255
\end{tabular}

Tabel Pengetahuan, digunakan untuk menyimpan pengetahuan bot untuk menjawab pertanyaan dari pengguna seperti pada Tabel 5 .

Tabel 5 Tabel pengetahuan

\begin{tabular}{lll}
\hline No & Nama & Tipe Data \\
\hline 1 & user_msg & text \\
\hline 2 & bot_msg & text \\
\hline 3 & id & int (11)
\end{tabular}

Tabel Percakapan, digunakan untuk menyimpan data percakapan antara bot dan pengguna seperti pada Tabel 6.

Tabel 6 Tabel percakapan

\begin{tabular}{lll}
\hline No & Nama & Tipe Data \\
\hline 1 & usemame & varchar (255 \\
\hline 2 & chat & text \\
\hline 3 & date & datetime \\
\hline 4 & id & int (11)
\end{tabular}

\section{Perancangan Antar Muka}

Perancangan antar muka dibuat menggunakan aplikasi Balsamiq untuk mempermudah dalam merancang aplikasi chatbot. Perancangan antar muka tersebut meliputi Halaman Utama, Halaman Awal Chatting, dan Halaman Chatting jika sudah berjalan. a. Halaman Utama

Halaman utama merupakan halaman yang pertama kali akan muncul ketika aplikasi diakses oleh pengguna seperti pada Gambar 9.

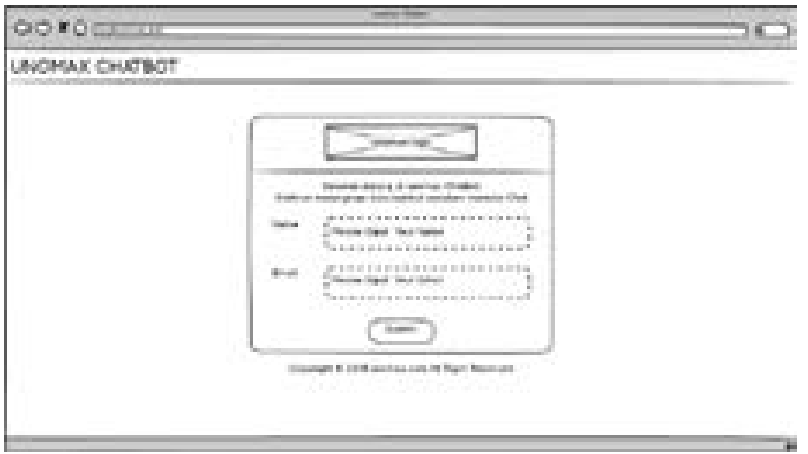

Gambar 9 Rancangan halaman utama

b. Halaman Awal Chatting

Halaman awal chatting merupakan halaman yang awal sebelum memulai percakapan antara pengguna dengan chatbot seperti pada Gambar 10.

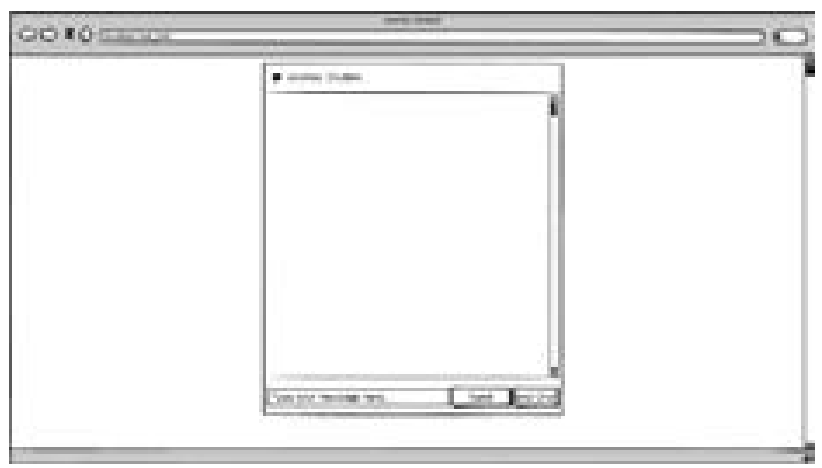

Gambar 10 Rancangan halaman awal chatting

c. Halaman Chatting

Halaman chatting merupakan halaman pada saat percakapan antara pengguna dengan chatbot berlangsung seperti pada Gambar 11 .

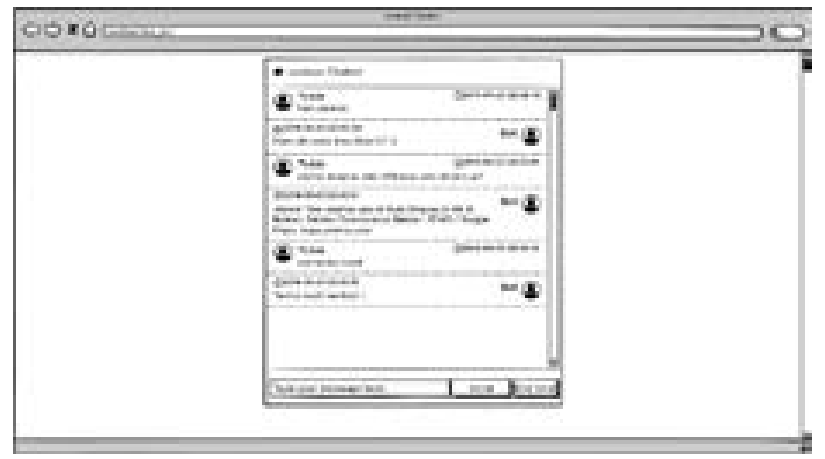

Gambar 11 Rancangan halaman chatting 


\section{Membangun Prototype}

Dalam tahap ini peneliti membangun prototype dengan membuat halaman web interaktif berdasarkan rancangan prototype yang sudah dibuat sebelumnya.

Implementasi antar muka adalah hasil dari implementasi koding ke dalam bentuk tampilan antar muka yang user friendly. Berikut ini adalah implementasi dari setiap halaman yang dibuat.

\section{a. Halaman Utama}

Halaman utama merupakan halaman yang pertama kali akan muncul ketika aplikasi diakses oleh pengguna seperti pada Gambar 12.

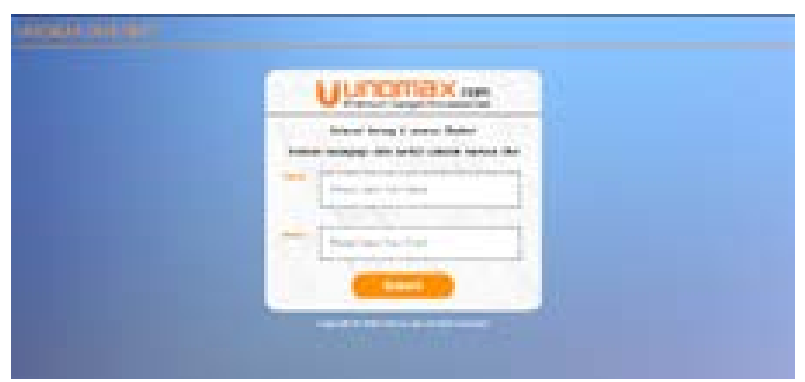

Gambar 12 Halaman utama

\section{b. Halaman Awal Chatting}

Halaman awal chatting merupakan halaman yang awal sebelum memulai percakapan antara pengguna dengan chatbot seperti pada Gambar 13.

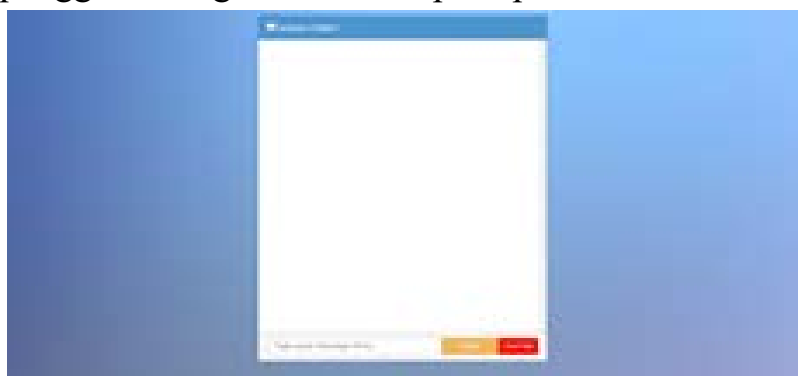

Gambar 13 Halaman awal chatting

\section{c. Halaman Chatting}

Halaman chatting merupakan halaman pada saat percakapan antara pengguna dengan chatbot berlangsung seperti pada Gambar 14.

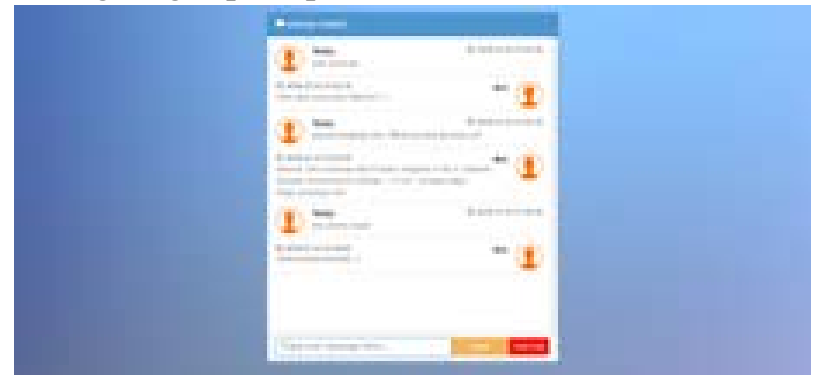

Gambar 14 Halaman chatting

\section{Evaluasi Prototype}

Secara keseluruhan dari perancangan dan implementasi prototype yang sudah dibuat, prototype sudah dibuat sesuai dengan keinginan pengguna. Peneliti mendemokan halaman web interaktif yang sudah dibuat kepada pengguna dan pengguna sudah merasa sesuai dengan apa yang diinginkan.

\section{E. Implementasi Aplikasi}

Pada bagian implementasi berisikan penjelasan mengenai aplikasi meliputi: batasan pengetahuan aplikasi, pengelolan pengetahuan aplikasi, implementasi antar muka, dan implementasi aplikasi.

Batasan Pengetahuan Aplikasi. Pada aplikasi chatbot ini, akan diberikan batasan-batasan pengetahuan chatbot yang akan digunakan dalam menjawab pertanyaan dari pengguna seperti pada Tabel 7.

Pengelolaan pengetahuan aplikasi ini menggunakan proses tokenisasi. Pertanyaan yang diajukan oleh pengguna akan dipecah berdasarkan karakter spasi menjadi kata-kata, kemudian dari hasil pemecahan kata tersebut akan dicari sesuai dengan keyword yang ada dalam pengetahun aplikasi. Dari hasil tersebut, pengguna mendapatkan jawaban yang sesuai pertanyaan yang diajukan. Dibawah ini adalah salah satu contoh kalimat pertanyaan yang dipecah berdasarkan karakter spasi menjadi kata-kata seperti pada Gambar 15.
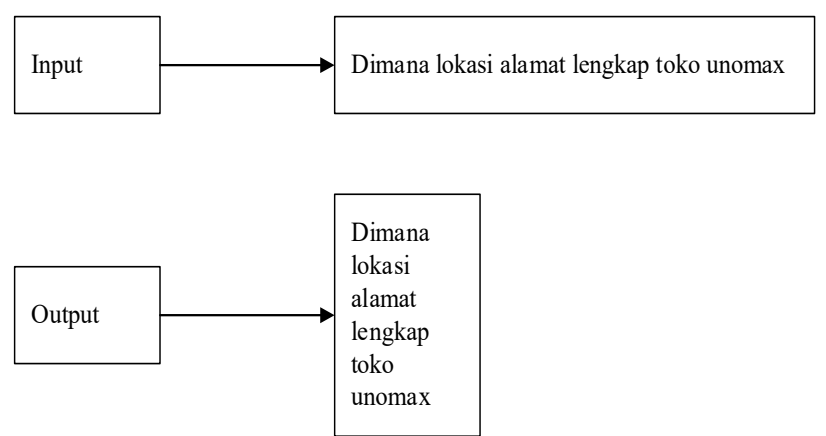

Gambar 15 Proses pemecahan kalimat

Implementasi Aplikasi. Tahap Implementasi aplikasi merupakan menterjemahan perancangan sistem yang sudah dibuat kedalam bentuk kode program agar dapat dimengerti oleh mesin serta penerapan perangkat lunak pada keadaan sesungguhnya. Seluruh kode program yang ditulis menggunakan bahasa pemrograman PHP dan MySQL.

\section{F. Pengujian Sistem}

Dalam tahap ini peneliti melakukan pengujian terhadap sistem yang telah dibuat menggunakan Black Box Testing.

Pengujian black box berfokus pada persyaratan fungsional perangkat lunak. Artinya, teknik pengujian 
Tabel 7 Batasan pengetahuan aplikasi2. pengelolaan pengetahuan aplikasi

\begin{tabular}{|c|c|c|}
\hline No & Keyword & Bot Reply \\
\hline 1 & $\begin{array}{l}\text { Keyword tidak } \\
\text { ditemukan }\end{array}$ & $\begin{array}{l}\text { Mohon maaf unomax Chatbot belum bisa menemukan jawaban atas } \\
\text { pertanyaan tersebut, untuk informasi lebih lanjut bisa menghubungi } \\
\text { CS unomax via Whatsapp di cs1.unomax.com }\end{array}$ \\
\hline 2 & halo & Halo ada yang bisa dibantu? :) \\
\hline 3 & pagi & Selamat Pagi ada yang bisa dibantu? :) \\
\hline 4 & siang & Selamat Siang ada yang bisa dibantu? :) \\
\hline 5 & sore & Selamat Sore ada yang bisa dibantu? :) \\
\hline 6 & malam & Selamat Malam ada yang bisa dibantu? :) \\
\hline 7 & gojek & $\begin{array}{l}\text { Untuk pengiriman via Gojek bisa melakukan order melalui } \\
\text { Tokopedia kami di tokopedia.com/unomax }\end{array}$ \\
\hline 8 & dropship & $\begin{array}{l}\text { Untuk pertanyaan seputar dropshipper bisa langsung mengunjungi } \\
\text { dropshipper.unomax.com ya }\end{array}$ \\
\hline 9 & garansi & $\begin{array}{l}\text { Apabila ada kerusakan atau cacat produk pada saat diterima maka } \\
\text { akan kami bantu tukar baru }\end{array}$ \\
\hline 10 & original & Semua produk yang unomax jual $100 \%$ Original ya \\
\hline 11 & terima kasih & Terima kasih kembali :) \\
\hline 12 & alamat & $\begin{array}{l}\text { Alamat Toko unomax ada di Ruko Sinpasa D-08 Jl. Bulevar Selatan } \\
\text { Summarecon Bekasi - } 17143 \text { / Google Maps: maps.unomax.com }\end{array}$ \\
\hline 13 & jam & $\begin{array}{l}\text { Jam Operasional Toko unomax Senin-Sabtu: } 08.00-19.30 \text { dan } \\
\text { Minggu: } 09.00-17.00\end{array}$ \\
\hline 14 & jasa pengiriman & Jasa Pengiriman yang tersedia ada JNE / J\&T / Gojek \\
\hline 15 & stock & $\begin{array}{l}\text { Untuk stock barang di website kami sudah paling update ya, bisa } \\
\text { dicek langsung pada keterangan produk yang diinginkan }\end{array}$ \\
\hline 16 & estimasi & $\begin{array}{l}\text { Untuk estimasi pengiriman berbeda-beda sesuai lokasi. Untuk } \\
\text { mengetahui estimasi pengiriman akan muncul pada saat melakukan } \\
\text { checkout }\end{array}$ \\
\hline 17 & ongkir & $\begin{array}{l}\text { Untuk harga ongkir pengiriman berbeda-beda sesuai lokasi dan jasa } \\
\text { pengiriman yang dipilih. Untuk mengetahui harga ongkir pengiriman } \\
\text { akan muncul pada saat melakukan checkout }\end{array}$ \\
\hline 18 & status & $\begin{array}{l}\text { Untuk pengecekan status pesanan akan diupdate melalui email yang } \\
\text { didaftarkan }\end{array}$ \\
\hline 19 & pemesanan & $\begin{array}{l}\text { Pemesanan bisa langsung melalui website kami atau apabila kesulitar } \\
\text { bisa dibantu via CS unomax via Whatsapp di csl.unomax.com }\end{array}$ \\
\hline 20 & resi & $\begin{array}{l}\text { Nomor Resi akan otomatis dikirimkan via email ya apabila sudah } \\
\text { dilakukan pengiriman }\end{array}$ \\
\hline 21 & marketplace & $\begin{array}{l}\text { unomax juga ada diberbagai marketplace seperti Tokopedia, } \\
\text { Bukalapak, Shopee, Lazada, Blibli, dll }\end{array}$ \\
\hline 22 & telepon & Nomor telepon kami yang bisa dihubungi 087787779508 \\
\hline 23 & line & Official Line@kami adalah@unomax \\
\hline 24 & garansi & $\begin{array}{l}\text { Kami memberikan garansi penukaran produk apabila produk rusak } \\
\text { saat diterima }\end{array}$ \\
\hline 25 & facebook & Facebook kami ada di fb.com/unomaxID \\
\hline 26 & instagram & Instagram kami ada di instagram.com/unomaxid \\
\hline 27 & pemasangan & Untuk pemasangan bisa dibantu di Toko Offline kami secara gratis \\
\hline 28 & pengiriman dari & Seluruh pengiriman produk kami dari Kota Bekasi \\
\hline
\end{tabular}

black box memungkinkan untuk membuat beberapa kumpulan kondisi masukan yang sepenuhnya akan melakukan semua kebutuhan fungsional untuk program [17].

Tahap pengujian black box testing merupakan proses melakukan evaluasi terhadap cara kerja sistem aplikasi yang sudah diimplementasikan dalam penelitian ini. Dalam pengujian black box testing hal ini, akan dibuat terlebih dahulu rencana pengujian dan skenario pengujian yang akan dilakukan terhadap sistem. Setelah dibuat rencana pengujian dan skenario pengujian maka akan dilakukan pengujian sistem apakah sudah sesuai atau belum dengan rencana pengujian dan skenario pengujian yang telah dibuat. Pada bagian akhir akan ditarik kesimpulan dari pengujian black box testing ini. 
a. Rencana Pengujian

Rencana pengujian yang dilakukan yaitu menguji sistem dapat dilihat pada Tabel 8 .

Tabel 8 Rencana pengujian sistem

\begin{tabular}{ll}
\hline \hline Requirement & Butir yang Diuji \\
\hline Data Pengguna & $\begin{array}{l}\text { Pengolahan nama dan email } \\
\text { pengguna }\end{array}$ \\
\hline Percakapan & $\begin{array}{l}\text { Pengolahan percakapan antara } \\
\text { pengguna dengan chatbot }\end{array}$ \\
\hline
\end{tabular}

b. Skenario Pengujian

Dari rencana pengujian yang dibuat, peneliti membuat skenario pengujian untuk memaparkan detail pengujian yang dapat dilihat pada Tabel 9 .

Tabel 9 Skenario pengujian

\begin{tabular}{|c|c|c|c|}
\hline Requirement & $\begin{array}{l}\text { Skenario } \\
\text { Uji }\end{array}$ & Kondisi & Hasil yang diharapkan \\
\hline \multirow{3}{*}{ Data Pengguna } & \multirow{3}{*}{$\begin{array}{l}\text { Input } \\
\text { username } \\
\text { dan email }\end{array}$} & Data benar & Masuk ke halaman chatting \\
\hline & & $\begin{array}{l}\text { Salah satu data } \\
\text { tidak diisi }\end{array}$ & $\begin{array}{l}\text { Muncul pesan "Silahkan masukkan } \\
\text { username dan email anda dengan } \\
\text { lengkap" }\end{array}$ \\
\hline & & $\begin{array}{l}\text { Email tidak diisi } \\
\text { dengan benar }\end{array}$ & $\begin{array}{l}\text { Muncul pesan "Masukkan email } \\
\text { dengan valid" }\end{array}$ \\
\hline \multirow[b]{2}{*}{$\begin{array}{l}\text { Percakapan } \\
\text { Chatting }\end{array}$} & \multirow[b]{2}{*}{$\begin{array}{l}\text { Input } \\
\text { pertanyaan }\end{array}$} & $\begin{array}{l}\text { Keyword } \\
\text { pertanyaan } \\
\text { ditemukan dalam } \\
\text { database }\end{array}$ & $\begin{array}{l}\text { Chatbot memunculkan jawaban } \\
\text { sesuai pertanyaan yang diajukan }\end{array}$ \\
\hline & & $\begin{array}{l}\text { Keyword } \\
\text { pertanyaan tidak } \\
\text { ditemukan dalam } \\
\text { database }\end{array}$ & $\begin{array}{l}\text { Chatbot menjawab "Mohon maaf } \\
\text { unomax Chatbot belum bisa } \\
\text { menemukan jawaban atas } \\
\text { pertanyaan tersebut, untuk } \\
\text { informasi lebih lanjut bisa } \\
\text { menghubungi CS unomax via } \\
\text { Whatsapp di cs1.unomax.com" }\end{array}$ \\
\hline
\end{tabular}

\section{c. Hasil Pengujian}

Dari rencana pengujian dan skenario pengujian yang telah dibuat, maka didapatkan hasil pengujian black box testing seperi pada Tabel 10 .

\begin{tabular}{|c|c|c|c|c|}
\hline Requirement & $\begin{array}{l}\text { Skenario } \\
\text { Uji }\end{array}$ & Kondisi & Hasil yang diharapkan & Kesimpulan \\
\hline \multirow{3}{*}{$\begin{array}{l}\text { Data } \\
\text { Pengguna }\end{array}$} & \multirow{3}{*}{$\begin{array}{l}\text { Input } \\
\text { username } \\
\text { dan email }\end{array}$} & Data benar & $\begin{array}{l}\text { Masuk ke halaman } \\
\text { chatting }\end{array}$ & Sesuai \\
\hline & & $\begin{array}{l}\text { Salah satu } \\
\text { data tidak diisi }\end{array}$ & $\begin{array}{l}\text { Muncul pesan "Silahkan } \\
\text { masukkan username dan } \\
\text { email anda dengan } \\
\text { lengkap" }\end{array}$ & Sesuai \\
\hline & & $\begin{array}{l}\text { Email tidak } \\
\text { diisi dengan } \\
\text { benar }\end{array}$ & $\begin{array}{l}\text { Muncul pesan "Masukkan } \\
\text { email dengan valid" }\end{array}$ & Sesuai \\
\hline \multirow[b]{2}{*}{$\begin{array}{l}\text { Percakapan } \\
\text { Chatting }\end{array}$} & \multirow[b]{2}{*}{$\begin{array}{l}\text { Input } \\
\text { pertanyaan }\end{array}$} & $\begin{array}{l}\text { Keyword } \\
\text { pertanyaan } \\
\text { ditemukan } \\
\text { dalam } \\
\text { database }\end{array}$ & $\begin{array}{l}\text { Chatbot memunculkan } \\
\text { jawaban sesuai pertanyaan } \\
\text { yang diajukan }\end{array}$ & Sesuai \\
\hline & & $\begin{array}{l}\text { Keyword } \\
\text { pertanyaan } \\
\text { tidak } \\
\text { ditemukan } \\
\text { dalam } \\
\text { database }\end{array}$ & $\begin{array}{l}\text { Chatbot menjawab } \\
\text { "Mohon maaf Chatbot } \\
\text { belum bisa menemukan } \\
\text { jawaban atas pertanyaan } \\
\text { tersebut, untuk informasi } \\
\text { lebih lanjut bisa } \\
\text { menghubungi CS unomax } \\
\text { via Whatsapp di } \\
\text { csl.unomax.com" }\end{array}$ & Sesuai \\
\hline
\end{tabular}

\section{d. Kesimpulan Pengujian Black Box Testing}

Dari pengujian diatas maka dapat disimpulankan bahwa aplikasi chatbot dapat berjalan dengan baik dan menjawab setiap pertanyaan dengan sesuai yang diharapkan. Maka dengan demikian, aplikasi chatbot ini sudah dinyatakan siap untuk diimplementasikan oleh CV Unomax Indonesia.

\section{SIMPULAN}

Setelah melakukan analisis, perancangan dan implementasi pada sistem yang telah dibuat, maka dapat disimpulan sebagai berikut: 1) Aplikasi Chatbot telah berhasil menanggapi pertanyaan pelanggan dengan cepat; 2) Aplikasi Chatbot memberikan informasi mengenai CV Unomax Indonesia, sehingga pelanggan lebih dimudahkan; 3) Aplikasi Chatbot mampu menangani banyaknya pertanyaan pelanggan tanpa adanya keterbatasan waktu pada jam kerja; 4) Dengan adanya Aplikasi Chatbot yang mampu menanggapi pertanyaan dengan cepat, CV Unomax Indonesia memberikan pelayanan terbaik kepada pelanggan; dan 5) Aplikasi Chatbot hanya menjawab pertanyaan yang sudah direpresentasikan di dalam database.

\section{DAFTAR RUJUKAN}

[1] S. R. D. Setiawan, "Tahun 2017, Pengguna Internet di Indonesia Mencapai 143,26 Juta Orang,” 2018. [Online]. Available: http://ekonomi.kompas.com. [Accessed 3 Maret 2018].

[2] S. S. Kute and S. D. Thorat, "A Review on Various Software Development Life Cycle(SDLC) Models," International Journal of Research in Computer and Communication Technology, vol. 3, no. 7, pp. 778-779, 2014.

[3] J. Hutahaen, in Konsep Dasar Sistem Informasi, Yogyakarta, Deepublish, 2014, pp. 1-13.

[4] Kusrin and K. Andri, in Membangun Sistem Informasi Akuntansi dengan VB \& Msc. SQL Server, Yogyakarta, Andi, 2010, p. 9.

[5] Yuhefizar, H. A. Mooduto and R. Hidayat, in Cara Mudah Membangun Website Interaktif Menggunakan Content Management System Joomla, Jakarta, PT Elex Media Komputindo, 2009, pp. 2-4.

[6] R. B. Santoso, "Rancang Bangun Prototype Chat Bot Customer Service System Berbasis Web,” Universitas Islam Negeri Sultan Syarif Kasim Riau, p. 6, 2013.

[7] B. Setiaji, E. Utami and H. A. Fatta, "Membangun Chatbot Berbasis AIML Dengan Arsitektur Pengetahuan Modular," Jurnal Seminar Nasional Teknologi Informasi dan Multimedia, vol. 1, no. 1, pp. 15-20, 2013.

[8] Kasmir, in Etika Customer Service, Jakarta, PT. RajaGrafindo Persada, 2006, p. 201.

[9] M. Khuda and B. Komputer, in Membuat Aplikasi Database dengan Java, MySQL dan Netbeans, Jakarta, PT. Elex Media Komputindo, 2010, p. 128. 
[10] Arief and M. Rudianto, in Pemrograman Web Dinamis Menggunakan Php dan Mysql, Yogyakarta, Andi Publisher, 2011, p. 152.

[11] B. Soeherman and M. Pinontoan, in Designing Information System, Jakarta, PT Elex Media Komputindo, 2008, pp. 134-138.

[12] E. Nilla and I. Afrianto, "Rancang Bangun Aplikasi Chatbot Informasi Objek Wisata Kota Bandung Dengan Pendekatan Natural Language Processing," Jurnal Ilmiah Komputer dan Informatika, vol. 4, no. 1, pp. 49-54, 2015.

[13] S. Gupta, et.al, "An E-Commerce Website Based Chatbot," International Journal of Computer Science and Information Technologies, vol. 6, no. 2, pp. 14831485, 2015.
[14] H. Joshi, et.al, "Proposal Of Chat Based Automated System For Online Shopping," American Journal of Neural Networks and Applications, vol. 3, no. 1, pp. $1-4,2017$.

[15] G. Urva and H. F. Siregar, "Pemodelan UML E-Marketing Minyak Goreng,” Jurnal Teknologi dan Sistem Informasi, vol. 1, pp. 93-95, 2015.

[16] R. Yanto, in Manajemen Basis Data Menggunakan MYSQL, Yogyakarta, Deepublish, 2016, pp. 30-52.

[17] R. S. Pressman, in Pendekatan Praktisi Rekayasa Perangkat Lunak, Yogyakarta, Andi, 2010, pp. 45-46. 